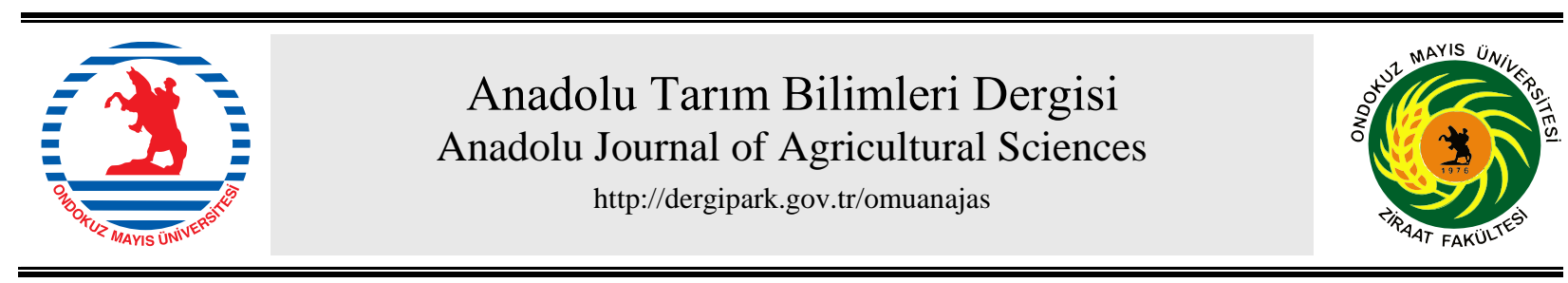

Araştırma/Research

Anadolu Tarım Bilim. Derg./Anadolu J Agr Sci, 35 (2020)

ISSN: 1308-8750 (Print) 1308-8769 (Online)

doi: 10.7161/omuanajas.768710

\title{
Bazı üzüm çeşitlerinde in vitro poliploidi uyarımı
}

\author{
그eki Kara ${ }^{\mathrm{a}}$, ํKevser Yazar ${ }^{\mathrm{a}}$ \\ ${ }^{a}$ Selçuk Üniversitesi, Ziraat Fakültesi, Bahçe Bitkileri Bölümü, Konya, Turkey
}

*Sorumlu yazar/corresponding author: kyazar@selcuk.edu.tr

Geliş/Received 13/07/2020＜noBreak>＜noBreak>Kabul/Accepted 31/08/2020

\begin{abstract}
ÖZET
Poliploidizasyon, kültür bitkilerinin üstün özelliklerinden önemli kayıp verilmeksizin genetik ilerleme sağlanması ve ıslah süresini kısaltması nedeniyle günümüzde sıklıkla tercih edilen bir 1slah yöntemidir. Bu çalışmada, sera koşullarında yetiştirilen Ekşi Kara, Gök Üzüm ve Trakya İlkeren (2x, Vitis vinifera L.) çeşitlerinin 2 yaşlı fidanlarından, aktif gelişme döneminde alınan tek boğum içeren mikro çelikler kullanılmıştır. Kimyasal mutagen olarak kullanılan kolhisin $\left(10 \mathrm{mg} \mathrm{L}^{-1}, 20 \mathrm{mg} \mathrm{L}^{-1}\right.$ ve $\left.30 \mathrm{mg} \mathrm{L}^{-1}\right)$, in vitro köklenme aşamasında otoklav sterilizasyonundan sonra, besin ortamı jel kıvamına gelmeden hemen önce filtre sterilizasyonu yapılarak MS ortamına ilave edilmiştir. Uygulamaların etkileri canlılık ve gelişme oranları, stoma sayısı ve boyutları, kloroplast sayımları ve flow sitometri (FC) analizleri ile incelenmiştir. Ekşi Kara, Gök Üzüm ve Trakya İlkeren çeşitlerinde kontrole göre stoma yoğunluğu değerlerinde en fazla azalış $10 \mathrm{mg} \mathrm{L}^{-1}$ (sırasıyla \% 48.90, \% 46.75, \% 50.97) uygulamasında belirlenmiștir. Stoma hücreleri kloroplast sayıları, kontrol Kyoho (4x) çeşidinde 38-40 adet aralığında değişim gösterirken, Ekşi Kara ve Gök Üzüm çeşitlerinde orijinal diploidlerine göre en belirgin artış 20 mg L $\mathrm{L}^{-1}$ kolhisin uygulamasında kaydedilmiştir. Dış koşullara alıştırma sonucunda canlılı̆̆ devam eden, kloroplast sayımlarında önemli farklılıklar belirlenen bitkiciklerde FC analizi yapılmıştır. Sınırlı sayıdaki örnekle yapılan FC analizlerinde, genotiplerin ploidi seviyesinin değişmediği $(2 \mathrm{n}=2 \mathrm{x})$ belirlenmiştir. Çalışma sonucunda in vitro düzeyde dokuların kolhisin uygulamalarına daha çabuk yanıt verdiği ve başarılı bir sonuç alınması amacıyla sonraki çalışmalarda eksplant tipi, uygulama dozu ve alıştırma koşulları konularının önem arz ettiği anlaşılmıştır.
\end{abstract}

\section{In vitro poliploidy induction in some grape cultivars}

\section{ABSTRACT}

Polyploidization is a breeding method that is frequently preferred today because of the genetic improvement and shortens of the breeding period without significant loss of the superior characteristics of the cultivated plants. In this study, single node micro cuttings taken from the 2-year old seedlings of Ekşi Kara, Gök Üzüm and Trakya İlkeren (2x, Vitis vinifera L.) cultivars grown in greenhouse conditions were used. Colchicine $\left(10 \mathrm{mg} \mathrm{L}^{-1}, 20 \mathrm{mg} \mathrm{L}^{-1}\right.$ and $\left.30 \mathrm{mg} \mathrm{L}^{-1}\right)$ which are used as chemical mutagen, was added to the MS medium after autoclave sterilization in vitro rooting, before the nutrient medium reached gel consistency. The effects of applications were investigated by viability and development rates, number and size of stomata, chloroplast counts and flow cytometry (FC) analysis. In Ekşi Kara, Gök Üzüm and Trakya İlkeren cultivars, the maximum decrease in stoma density values were determined in the $10 \mathrm{mg} \mathrm{L}^{-1}$ application (48.90\%, 46.75\%, 50.97\% respectively). Stoma cells chloroplast counts varied in the control Kyoho $(4 \mathrm{x})$ cultivar in the range of 38-40, while the most significant increase in Ekşi Kara and Gök Üzüm cultivars compared to the original diploids was recorded in the $20 \mathrm{mg} \mathrm{L}^{-1}$ colchicine application. FC analysis was carried out in plantlets whose vitality was maintained after acclimatization and significant differences were determined in chloroplast counts. In FC analyzes with a limited number of samples, it was determined that the ploidy level of the genotypes did not change $(2 n=2 x)$. As a result of the study, it was understood that in vitro tissues respond to the applications of colchicine more and to get a successful result, type of explant, application dose and conditions are important in further studies.
Anahtar Sözcükler:

Asma

Islah

Kimyasal mutagen

Mitotik poliploidi

Ototetraploidi

Keywords:

Grapevine

Breeding

Chemical mutagen,

Mitotic polyploidy

Autotetraploidy

(c) OMU ANAJAS 2020 


\section{Giriş}

Asma dünyada yetiştiriciliği yapılan en önemli bitki türlerinden birisidir. Global olarak 77.8 milyon ton üzüm üretiminin \%36's1 sofralıktır (OIV, 2017b). Üretim bakımından önde gelen ülkeler arasında yer alan Türkiye'de ise toplam üretimin yaklaşık \%50'si sofralık olarak değerlendirilmektedir (TÜİK, 2018). Ülkemizin mevcut pazarda yerinin korunması ve geliştirilmesi, tüketici ve pazar talepleri doğrultusunda yerli ve yöresel üzüm çeşitlerimizin özelliklerinin geliştirilmesi gerekmektedir.

Poliploidi, hücre çekirdeğinin ikiden fazla tam kromozom takımına sahip olması olarak tanımlanmaktadır. Bitkilere büyük bir adaptasyon ve türleşme mekanizması sağlaması nedeniyle (Ramsey ve Schemske, 1998) birçok türde çeșitli fiziksel ve kimyasal antimitotiklerle yapay olarak teşvik edilmektedir. Kolhisin, mitoz bölünmenin metafaz aşamasında iğ iplikciklerinin gelişimini engelleyerek genom düzeyinde katlama sağlamak üzere kullanılmaktadır (Ramsey ve Schemske, 1998; Planchais ve ark., 2000). Yapılan çalışmalarda, allopoliploidi ve otopoliploidinin her ikisinin de doğada yaygın olmalarıyla birlikte çoğu poliploid türün alloploid orijinlere sahip olduğu gösterilmiştir (Ramsey ve Schemske, 1998). Ploidinin kesin etkileri, somatik kromozom katlamasıyla elde edilen, donör bitkilerden sadece genom büyüklüğü bakımından farklılık gösteren otopoliploidlerde belirlenebilmektedir (Cohen ve ark., 2013). Poliploidi asma islahından 1937 'den beri kullanılmakta ve son yıllarda ilgi giderek artmaktadır (Olmo, 1937). Japonya'da 1945 'te 1 slah edilen (Kunter ve Karataş, 2011; Yamada ve Sato, 2016) 'Kyoho', Çin başta olmak üzere global olarak en büyük bağ alanına sahip poliploid çeşittir (OIV, 2017a).

Poliploidizasyona yönelik 1slah çalışmalarında in vitro, kromozom katlama uygulamalarının yapılabileceği kontrollü bir ortam sağlamakta ve saf poliploidlerle miksoploidlerin ayırt edilmesinde kullanılmaktadır (Chen ve Gao, 2007; Aleza ve ark., 2009). Önceki çalışmalarda, poliploidi uyarımı için uygulama dozu, süresi, doku tipi ve uygulama yöntemleri bakımından etkinlik farklılıkları (Acanda ve ark., 2013; Xie ve ark., 2015; Ekbiç ve Tangolar, 2016) ve geleneksel ıslah çalışmalarına alternatif olarak, kültür çeşitlerinde iyileşmeler sağlandığı bildirilmektedir (Notsuka ve ark., 2000; Yamada ve Sato, 2016).

'Ekşi Kara' ve 'Gök Üzüm', Orta Toroslarda ekolojiye iyi uyum sağlamaları nedeniyle yoğun olarak yetiştirilen geleneksel üzüm çeşitleridir. Ekşi Kara çeşidinin tozlayıcı ihtiyacının (Kara ve ark., 2017) ve meyve kalitesinin iyileştirilmesi gerekmektedir.

$\mathrm{Bu}$ çalışmada in vitro koşullarda, kolhisin uygulamalarının farklı üzüm çeşitlerinde poliploidiye etkileri incelenmiştir.

\subsection{Bitkisel materyal}

Çalışmada, Selçuk Üniversitesi Ziraat Fakültesinde klon seleksiyonu ile seçilmiş otokton Ekşi Kara ve Gök Üzüm çeşitleri ile Tekirdağ Bağcılık Araştırma Enstitüsünden temin edilen Trakya İlkeren üzüm çeşitleri kullanılmıştır. Uygulamalar sonrasında bitkiciklerin. stoma hücrelerindeki kloroplast sayıları tetraploid (4X) 'Kyoho' ile karşılaş̧ırılmıştır (Yamada ve Sato, 2016). Ekşi Kara ve Gök Üzüm, KonyaKaraman illeri ve Orta Toroslara iyi adapte olmuş, yörede en çok yetiştirilen çeşitler konumundadırlar. Her iki çeşit de sofralık, kurutmalık olarak değerlendirilmektedir (Kara ve ark., 2017). Tekirdağ Bağcılık Araştırma Enstitüsü tarafından 1slah edilen 'Trakya İlkeren', erkenci bölgelerimizin yanısıra, Orta Toroslarda kısa vejetasyonlu bağ alanlarında da başarılı olabilmektedir (Kara ve Demirhan, 2005).

\subsection{Kimyasal mutagen kolhisin uygulamalart}

Sera koşullarında yetiştirilen 2 yaşlı fidanlardan uygun materyal elde etmek amaciyla, aktif gelişme döneminde eksplant alınmış (Gray ve Benton, 1991; Di Genova ve ark., 2014) ve tek boğumlu mikro çelikler hazırlanmıştır. Yüzey sterilizasyonu (dikey hava akışlı steril kabinde), mikro çeliklerin \%70'lik etanol içinde 2 dakika ve sonrasında \%12'lik sodyum hipoklorit (NaOCl) çözeltisinde 15 dakika süreyle bekletilmesi ve ardından 3 kez steril saf su ile çalkalanmasıyla tamamlanmıştır. Mikro çelikler yüzey sterilizasyonundan sonra Murashige Skoog (MS) ortamı (\% 3 sükroz, \% 0.7 agar) içeren kavanozlara yerleştirilmiştir (Murashige ve Skoog, 1962). Başlangıç ve sürgün oluşturma aşamalarında ortama, Trakya İlkeren çeşidinde $1 \mathrm{mg} \mathrm{L}^{-1}$, Ekşi Kara ve Gök Üzüm çeşitlerinde $0.8 \mathrm{mg} \mathrm{L}^{-1} \mathrm{BAP}$, köklendirme aşamasında ise tüm çeşitler için $1 \mathrm{mg} \mathrm{L}^{-1}$ IBA eklenmiş, eksplantlarda bakteri oluşumunu engellemek için, 0.25 $\mathrm{mg} \mathrm{L}^{-1}$ dozunda geniş spektrumlu antibiyotik (Seffur) ilave edilmiştir (Mbah ve Wakil, 2012). Kültür ortamındaki eksplantlar, iklim odasında $\left(25 \pm 1^{\circ} \mathrm{C}\right) 3000$ lüks $\mathrm{m}^{-2}$ aydınlatma şiddetinde 1şık kaynağı olan raflara konularak, 16 saat aydınlık 8 saat karanlık foto periyotta geliştirilmiştir (Notsuka ve ark., 2000). Poliploidinin uyarılması amaciyla kolhisin (Sigma-Aldrich, $10 \mathrm{mg} \mathrm{L}-$ 1, $20 \mathrm{mg} \mathrm{L}^{-1}$ ve $30 \mathrm{mg} \mathrm{L}^{-1}$ ) \%1 Dimetilsülfoksit (DMSO) içerisinde çözülerek, köklenme aşamasında otoklav sterilizasyonundan $\left(121{ }^{\circ} \mathrm{C}^{\prime} \mathrm{de} 15 \mathrm{dk}\right)$ sonra besin ortamı jel kıvamına gelmeden hemen önce 0.2 mikrometre çapında filtre (Sartarius Minisart NML) ile sterilize edilerek ilave edilmiştir. Eksplantlara, köklendirme aşamasında 4 hafta süre ile kolhisin uygulaması yapılmıştır. Bu süre sonunda, köklenerek gelişmesine devam eden bitkiciklerin, kök bölgeleri ılık suda temizlenerek fungusitle muamele edilmiş ve eşit oranda steril torf ve perlit ile hazırlanmış harç bulunan

\section{Materyal ve Yöntem}


polietilen kaplara dikilmiş̧lerdir. Dış ortama alışan bitkiler daha sonra sera koşullarına aktarılmıştır.

\subsection{Ploidi düzeyinin belirlenmesi}

\subsubsection{Canlılık oranı (\%)}

Köklendirme aşamasında kolhisin uygulaması yapılmış mikro çeliklerde canlılık oranı, canlılı̆̆ devam eden mikro çeliklerin aktarılan mikro çeliklere oranlanması ile (\%) belirlenmiştir (Tepe ve ark., 2002; Sinski ve ark., 2014).

\subsubsection{Gelişme oranı (\%)}

Kolhisin uygulanan mikro çeliklerde gelişme oranı, sürgün oluşturan ve köklenerek gelişmesine devam eden mikro çeliklerin, canlı mikro çeliklere oranlanması ile (\%) belirlenmiştir (Tepe ve ark., 2002; Sinski ve ark., 2014).

\subsubsection{Stoma yoğunluğu (adet $\mathrm{mm}^{-2}$ ), stoma genişliği $(\mu \mathrm{m})$, stoma uzunluğu $(\mu \mathrm{m})$ gözlemleri}

Uygulama yapılan bitkilerin yaprak epidermal izleri uygulama yapıldıktan sonra gelişen sürgünlerde aklimitizasyon sırasında alınan yaprağın alt tarafında incelenmiştir. Üç farklı bölgeye şeffaf oje sürülmesiyle alt epidermis sıyrılıp alınarak lam üzerine yerleştirilmiş ve stoma sayısı, genişliği ve uzunluğu, $\times 400$ mikroskopla tespit edilmiştir (Moghbel ve ark., 2015).

\subsubsection{Kloroplast sayımı (adet stoma ${ }^{-1}$ )}

Uygulamalar sonrasında canlılığı devam eden ve aklimitizasyona alınmış bitkilerin hepsinde stoma bekçi hücrelerinde kloroplast sayısı değişimleri incelenmiştir. Stoma örneği için alınan yaprak örneklerinde yaprak kesitlerinin, Carnoy solüsyonunda (3 k1sım etil alkol: 1 kısım glasiyal asetik asit) rengi açılmıştır. Solüsyondan çıkartılan yaprak kesitleri 2-5 dakika steril suda bekletilmiş ve ardından 30 saniye \%1'lik I-KI ile boyanmıştır. Her örnekte 30 adet stoma da kloroplast sayımı yapılmıştır. Kloroplast sayıları $\times 400$ mikroskopta tespit edilmiş (Yuan ve ark., 2009), diploid ebeveynleri ve tetraploid (4x) 'Kyoho' üzüm çeşidi ile karşılaştırılmıştır.

\subsubsection{Flow sitometri (FC) analizi}

Her uygulama için taze yaprak örneklerinden (3-4 haftalık) kesitler alınarak $0.5 \mathrm{~cm}^{2}$ büyüklüğündeki petri kabına yerleştirilmiş ve $500 \mu \mathrm{L}$ izolasyon buffer (Partec-Nuclei Extraction Buffer) ilave edilerek yaprak dokusu jilet ile küçük parçalara ayrılmıştır. Petri kabındaki örnekler 10-15 saniye süreyle çalkalanmış ve Partec-CellTrics $30 \mu \mathrm{m}$ - green filtre ile süzülerek tüp içerisine (Partec-Sample Tubes, $3.5 \mathrm{ml}, 55 \times 12 \mathrm{~mm}$ ) aktarılmıştır. Tüplere $1600 \mu \mathrm{L}$ boyama solüsyonu [Partec-DAPİ (4,6 diamidino-2-phenylinole) Staining Buffer] ilave edilerek ışı izolasyonu olan bir ortamda 5 dakika bekletilmiştir. Sonrasında örnekler FC cihazında analiz edilmiştir (Tuna, 2014).

\subsubsection{Istatistiksel analiz}

Deneme, tesadüf parselleri deneme deseninde, 3 tekerrürlü ve her tekerrürde 20 adet mikro çelik olacak şekilde gerçekleştirilmiştir. Uygulamaların etkileri SPSS 22 istatistik programında Duncan çoklu karşılaştırma testi ile $\mathrm{p}<0.05$ önem seviyesinde karşılaştırılmıştır (Yue ve ark., 2017).

\section{Bulgular ve Tartışma}

\subsection{Canlllık oranı (\%)}

Kolhisin uygulamalarının mikro çeliklerde canlılık oranlarına (\%) etkisi önemli $(\mathrm{p}<0.05)$ bulunmuştur (Çizelge 1). Ekşi Kara, Trakya İlkeren ve Gök Üzüm çeşitlerinde kolhisin uygulamalarındaki doz artışı ile ters orantılı olarak mikro çeliklerin canlılık oranları azalmıştır. Tüm çeşitlerde en düşük canlılık oranları 30 mg L L ${ }^{-1}$ kolhisin uygulamasında kaydedilmiştir. Ekşi Kara üzüm çeşidinde kontrolde canlılık oranı \% 89.48 iken en düşük canlılık oranı $30 \mathrm{mg} \mathrm{L}^{-1}$ kolhisin uygulamasında (\% 45.67) tespit edilmiştir. Çalışmada Trakya İlkeren çeşidi in vitro koşullara diğer iki çeşide oranla daha yüksek hassasiyet göstermesi sebebiyle kolhisinin toksik etkisinden daha çok etkilenmiş, canlılık oranları daha düşük düzeylerde kalmıştır.

In vitro koşullarda yapılan poliploidi çalışmalarında kimyasal antimitotik ile düşük konsantrasyonlarda ya da daha kısa sürelerle uygulama yapılması ile canlılık oranlarında azalma görülmemekte fakat genom katlanma frekansı düşmektedir (Väinölä, 2000; Xie ve ark., 2015). Acanda ve ark. (2013), tarafindan kolhisin doz artışıla kallus yüzeyindeki embriyonik hücrelerin, antimitotik ajana daha çok maruz kalması nedeniyle embriyonik potansiyelin, canlılık oranlarına göre daha fazla düşüş gösterdiği bildirilmiştir. Yang ve ark. (2006), benzer şekilde, kolhisin doz ve uygulama süresi artışına paralel olarak embriyo canlılık oranlarının azaldığını, en düşük canlılığın (\%26) $20 \quad \mathrm{mg} \mathrm{L}^{-1}$ uygulamasından alındığını bildirmişlerdir. Bizim çalışmamızda kolhisinin köklenme aşamasında ortama ilave edilmesiyle, kolhisine maruz kalma süresi uzatılmış, bu sebeple canlılık değerlerinde kontrole göre önemli oranda azalış gözlenmekle birlikte literatürle benzerlik tespit edilmiştir.

\subsection{Geliş̧me oranı (\%)}

Uygulanan kimyasal mutagenin doz artışına bağlı olarak mikro çeliklerin gelişme oranlarında önemli 
$(\mathrm{p}<0.05)$ azalma belirlenmiştir. Canlılık oranlarında olduğu gibi, tüm çeşitlerde $30 \mathrm{mg} \mathrm{L}^{-1}$ kolhisin uygulanan mikro çeliklerin gelişmeleri yavaşlamış, Ekşi Kara, Trakya İlkeren ve Gök Üzüm çeşitlerinde gelişme oranları sirasıyla \% 32.00, \% 35.78, \% 35.15 olarak belirlenmiştir (Şekil 1). Kolhisin konsantrasyonu ve uygulama süresi kombinasyonları poliploidi başarısını etkileyen önemli faktörlerdir (Huy ve ark., 2019). Ancak, doz ve uygulama süresindeki artışla birlikte bitki materyalinin canlılık ve gelişme oranları olumsuz yönde etkilenmektedir (Tepe ve ark., 2002; Sinski ve ark., 2014). Zhou ve ark. (2020) tarafindan yapılan çalışmada, kolhisin uygulamalarının görülebilir ilk etkisi gelişmenin yavaşlaması olarak belirtilmiş ve kontrolde 3-4 gün olan gelişme başlangıcının kolhisin uygulamalarıyla 10-15. günlere kadar geciktiği bildirilmiştir. Çalışmadan elde edilen veriler önceki çalışmaları destekler niteliktedir.

Çizelge 1. Uygulamaların canlılık oranlarına (\%) etkileri *

Table 1. Effects of applications on viability rate (\%)

\begin{tabular}{ccccc}
\hline & $\begin{array}{c}\text { Kültüre alınan } \\
\text { mikro çelik } \\
\text { saylsl }\end{array}$ & Ekşi Kara & Gök üzüm & Trakya Illkeren \\
\hline Kontrol & 60 & $89.48 \pm 1.78 \mathrm{a}$ & $93.67 \pm 1.53 \mathrm{a}$ & $84.76 \pm 0.67 \mathrm{a}$ \\
$10 \mathrm{mg} \mathrm{L}^{-1}$ & 60 & $63.49 \pm 2.17 \mathrm{~b}$ & $74.48 \pm 2.81 \mathrm{~b}$ & $56.00 \pm 3.61 \mathrm{~b}$ \\
$20 \mathrm{mg} \mathrm{L}^{-1}$ & 60 & $52.05 \pm 3.63 \mathrm{c}$ & $52.60 \pm 2.16 \mathrm{c}$ & $42.00 \pm 2.00 \mathrm{c}$ \\
$30 \mathrm{mg} \mathrm{L}^{-1}$ & 60 & $45.67 \pm 2.08 \mathrm{~d}$ & $46.43 \pm 3.12 \mathrm{~d}$ & $37.92 \pm 2.79 \mathrm{c}$ \\
\hline
\end{tabular}

* Duncan çoklu karşılaştırma testine göre \%5 düzeyinde farklılık gösteren gruplar aynı sütunda farklı harflerle ifade edilmiştir.

* According to Duncan's multiple comparison test the groups differing at the level of 5\% were expressed in different letters in the same column.

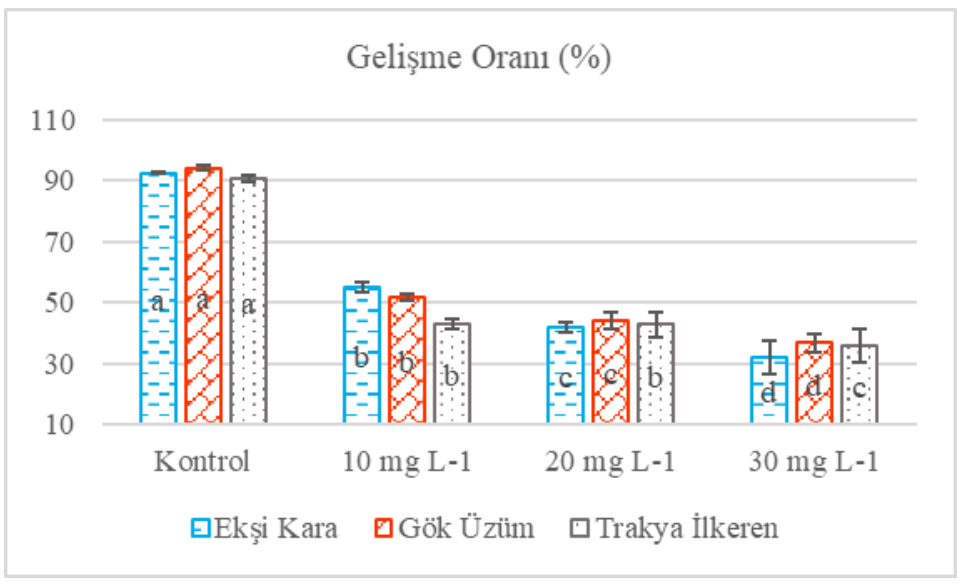

Şekil 1. Uygulamaların gelişme oranlarına (\%) etkileri

Figure1.Effects of applications on growth rate (\%)

3.3. Stoma yoğunluğu (adet $\mathrm{mm}^{-2}$ ), stoma genişliği ( $\left.\mu \mathrm{m}\right)$, Stoma uzunluğu ( $\mu \mathrm{m})$ gözlemleri

Kolhisin uygulamaları sonucunda çeşitlerin yaprak stoma uzunluğu değerleri değişen oranlarda etkilenmiştir $(p<0.05)$. Ekşi Kara ve Trakya İlkeren çeşitlerinde kontrole göre en yüksek stoma uzunluğu değeri $20 \mathrm{mg} \mathrm{L}^{-1}$ (sırasıly $25.55 \mu \mathrm{m}, 23.44 \mu \mathrm{m}$ ), Gök Üzüm çeşidinde ise $10 \mathrm{mg} \mathrm{L}^{-1}(28.88 \mu \mathrm{m})$ uygulamasında belirlenmiştir (Şekil 2).

Stoma genişliği değerleri, stoma uzunluğu değerlerine benzer şekilde uygulama bazında aynı gruplarda artış göstermiştir. Gök Üzüm ve Trakya İlkeren çeşitlerinde stoma genişliği değerlerinde en fazla değişim $10 \mathrm{mg} \mathrm{L}^{-1}$ (sırasıyla $19.55 \mu \mathrm{m}, 18.11 \mu \mathrm{m}$ ), uygulamasında, Ekşi Kara çeşidinde ise $20 \mathrm{mg} \mathrm{L}^{-1}$ $(22.56 \mu \mathrm{m})$ uygulamasında tespit edilmiştir (Şekil 3).

Kolhisin uygulaması ve kontrol örneklerde yapilan mikroskobik gözlemlerde stoma yoğunluğunun, stoma uzunluğu ve genişliği değerlerindeki artışa bağlı olarak azalış gösterdiği belirlenmiştir Ekşi Kara, Gök Üzüm ve Trakya İlkeren çeşitlerinde kontrole (sırasıyla 420.29, 427.54, 427.54 adet $\mathrm{mm}^{-2}$ ) göre stoma yoğunluğu değerlerinde en fazla azalış $10 \mathrm{mg} \mathrm{L}^{-1}$ (sırasıyla \% 48.90, \% 46.75, \% 50.97) uygulamasında belirlenmiş̧ir (Şekil 4). 
Poliploidinin teşvik edildiği genotiplerde genel olarak birim yaprak alanına düssen stoma ve epidermal hücre sayısı azalırken stoma bekçi hücrelerinin uzunluğu ve genişliği artış göstermektedir (Yuan ve ark., 2009; Sattler ve ark., 2016). Sinski ve ark. (2014), $2 \mathrm{x}$ ve $4 \mathrm{x}$ kromozom sayısına sahip genotiplerde stoma boyutlarını belirlemişler ve tetraploid bitkilerin stoma boyutlarında artışla birlikte birim alandaki stoma sayısında azalma meydana geldiğini bildirmiş̧lerdir. Çalışmadan elde edilen veriler ploidi ile ilgili yapılan çalışmalarla benzer olup stoma boyutlarındaki artışa bağlı olarak yoğunluğunda azalışlar kaydedilmiştir.

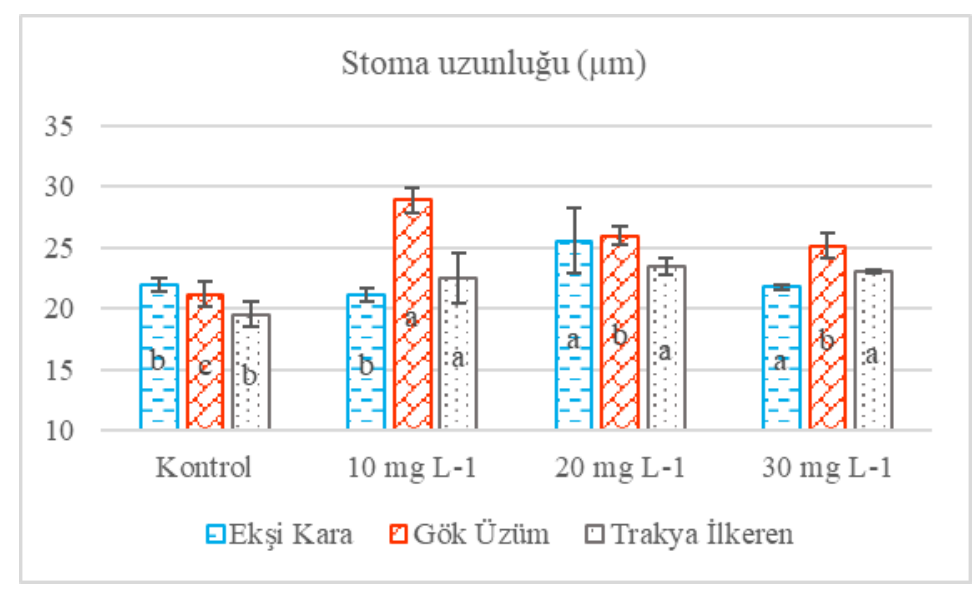

Şekil 2. Uygulamaların stoma uzunluğu $(\mu \mathrm{m})$ üzerine etkileri

Figure 2. Effects of applications on stoma length $(\mu \mathrm{m})$

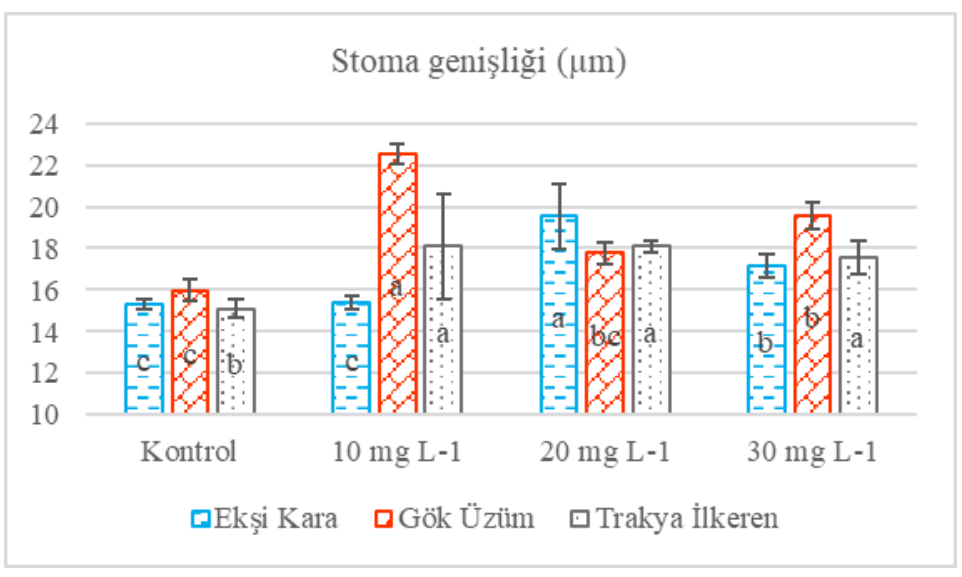

Şekil 3. Uygulamaların stoma genişliği $(\mu \mathrm{m})$ üzerine etkileri

Figure 3. Effects of applications on stoma width $(\mu \mathrm{m})$ 


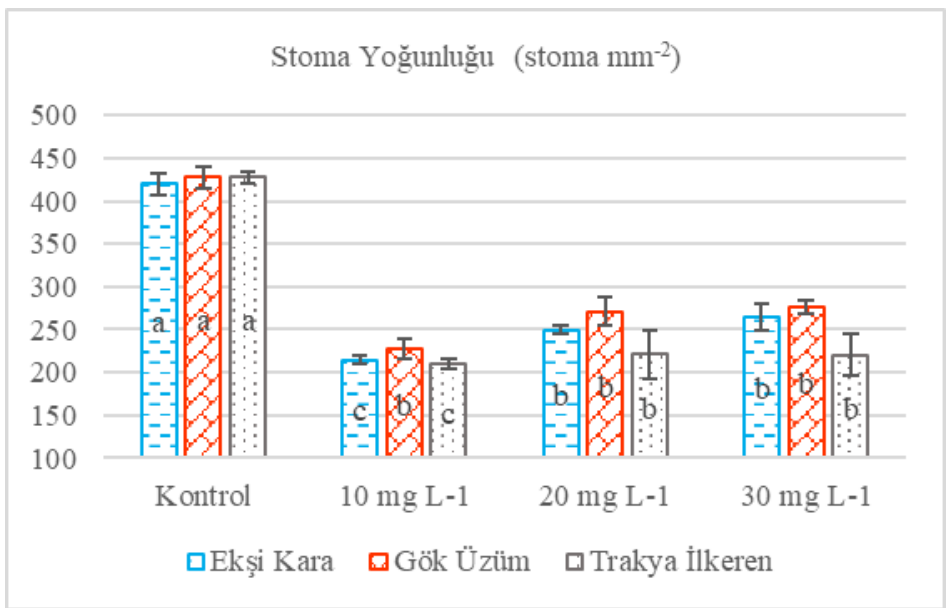

Şekil 4. Uygulamaların stoma yoğunluğu (adet $\mathrm{mm}^{-2}$ ) üzerine etkileri

Figure4. Effects of applications on stomata density (adet $\mathrm{mm}^{-2}$ )

\subsection{Kloroplast sayımı (adet stoma ${ }^{-1}$ ) sonuçları}

Kolhisin uygulanan üzüm çeşitlerinin yaprak örneklerinde tespit edilen stoma hücrelerindeki kloroplast sayıları arasındaki farklılık önemli $(\mathrm{p}<0.05)$ bulunmuştur. Çalışmada kontrol 'Kyoho' (4x) stoma hücrelerinde kloroplast sayılarının 38-40, aralı̆̆ında değiştiği tespit edilmiştir. Ekşi Kara, Gök Üzüm ve Trakya İlkeren çeşitlerinde kontrole göre (sırasıyla 19.76, 20.94, 19.28 adet stoma ${ }^{-1}$ ) en belirgin artış, Ekşi Kara çeşidinde $20 \mathrm{mg} \mathrm{L}^{-1}$ (23.44 adet stoma $\left.{ }^{-1}\right)$, Gök Üzüm çeşidinde ise $10 \mathrm{mg} \mathrm{L}^{-1}$ (24.91 adet stoma $\left.{ }^{-1}\right), 20$ $\mathrm{mg} \mathrm{L}^{-1}$ (25.45 adet stoma ${ }^{-1}$ ) ve $30 \mathrm{mg} \mathrm{L}^{-1}$ (24.41 adet stoma $^{-1}$ ) uygulamalarında belirlenmiştir (Çizelge 2, Şekil 5). Stoma bekçi hücrelerindeki kloroplast gözlemlerinin, ploidi ön tespiti amacıyla sıklıkla kullanıldığı kolay, hızlı ve güvenilir sonuçlar verdiği bilinmektedir (Yang ve ark., 2006; Yuan ve ark., 2009). Xie ve ark. (2015) tarafindan, in vitro koşullarda tetraploidinin uyarılması için protokol oluşturulmaya çalışılmış ve farklı eksplant kaynaklarının, kolhisin ve orizalin ile muamelesinden sonra stoma verilerinin (stoma boyutu ve sayıları, bekçi hücrelerdeki kloroplast sayıları) ploidi seviyesi ile korelasyon gösterdiği kaydedilmiştir.

In vitro mikro çoğaltım sonrasında üretilen çoğu bitkinin dış koşullara alıştırma esnasında hayatta kalamadığ 2012). Köklendirme aşamasında kullanılan hormon konsantrasyonu (Kumar ve Rao, 2012), kültür koşullarından kaynaklanan anormal yaprak anatomisi ve fizyolojisi bitkiciklerin sera koşullarına alıştırılmasını zorlaştıran nedenler arasında yer almaktadır (Dami ve Hughes, 1995; Torregrosa ve ark., 2001). Çalışmada köklendirme aşamasındaki bitkicikler, kültür koşullarına ek olarak uzun süreli kolhisin etkisine maruz kalmış ve dış koşullara alıştırma aşamasında canlılık oranlarının düşük olduğu gözlenmiştir. Bu sebeple, stoma boyutları ve kloroplast sayıları değerlendirilerek ploidi seviyesinin değiştiği düşünülen bitkiciklerin çoğunda flow sitometri analizi gerçekleştirilememiştir.

Çizelge 2. Uygulamaların kloroplast sayısı (adet stoma ${ }^{-1}$ ) üzerine etkileri*

Table 2. Effects of applications on chloroplast number (adet stoma $\left.{ }^{-1}\right)^{*}$

\begin{tabular}{cc|cccccc}
\hline & & \multicolumn{2}{|c}{ Ekşi Kara } & \multicolumn{2}{c}{ Gök Üzüm } & \multicolumn{2}{c}{ Trakya İlkeren } \\
\hline & Stoma & Ortalama & Aralık & Ortalama & Aralık & Ortalama & Aralık \\
& Sayıs1 & & & & & & \\
Kontrol & 30 & $19.76 \pm 0.42 \mathrm{~b}$ & $18-20$ & $20.94 \pm 0.48 \mathrm{~b}$ & $18-22$ & $19.28 \pm 1.11 \mathrm{a}$ & $18-20$ \\
$10 \mathrm{mg} \mathrm{L}^{-1}$ & 30 & $22.95 \pm 0.47 \mathrm{a}$ & $18-24$ & $24.91 \pm 2.60 \mathrm{a}$ & $18-38$ & $20.33 \pm 1.53 \mathrm{a}$ & $18-22$ \\
$20 \mathrm{mg} \mathrm{L}^{-1}$ & 30 & $23.44 \pm 3.01 \mathrm{a}$ & $18-38$ & $25.45 \pm 2.24 \mathrm{a}$ & $18-38$ & $20.26 \pm 0.68 \mathrm{a}$ & $18-22$ \\
$30 \mathrm{mg} \mathrm{L}^{-1}$ & 30 & $21.58 \pm 2.74 \mathrm{ab}$ & $18-22$ & $24.41 \pm 1.31 \mathrm{a}$ & $18-38$ & $20.26 \pm 1.01 \mathrm{a}$ & $18-22$ \\
\hline
\end{tabular}

* Duncan çoklu karşılaştırma testine göre \%5 düzeyinde farklılık gösteren gruplar aynı sütunda farklı harflerle ifade edilmiştir.

* According to Duncan's multiple comparison test the groups differing at the level of 5\% were expressed in different letters in the same column. 


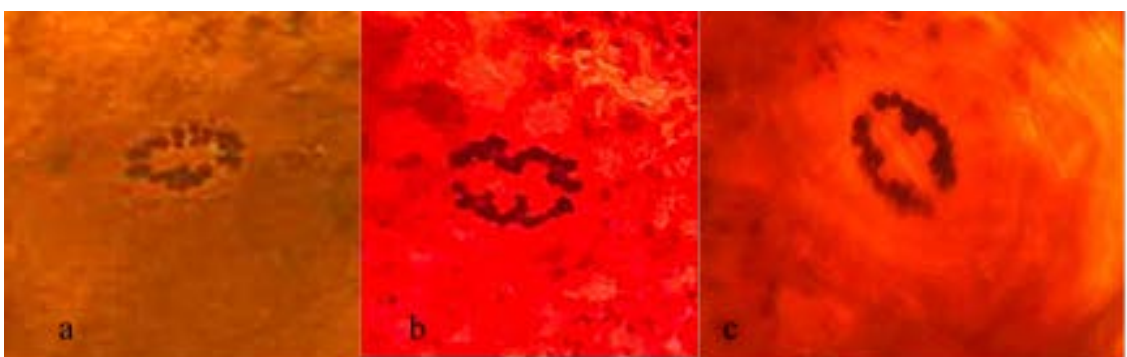

Şekil 5. 'Ekşi Kara' 20 mg L'-1, stoma hücreleri kloroplast sayıları (38-40, x400), b. 'Gök Üzüm’ 20 mg L'-1, stoma hücreleri kloroplast sayıları ((38-40, x400), c 'Kyoho' stoma bekçi hücreleri kloroplast sayıları (38-40,x1000)

Figure 5. a. The number of stomatal cells chloroplasts (38-40, x400) in 'Ekşi Kara' $20 \mathrm{mg} \mathrm{L}^{-1}, \mathrm{~b}$ The number of stomatal cells chloroplasts (38-40, x400) in 'Gök Üzüm' 20 mg L'-1 b. Stomata guard cells of 'Kyoho' cv. $(x 1000)$

\subsection{Flow sitometri analiz sonuçları}

Dış koşullara alıştırma sonucunda canlılığ devam eden bitkiciklerde, kloroplast sayımları temel alınarak FC analizi yapılmıştır. Sınırlı sayıda bitki örneğinde yapılan FC analizleri sonucunda, genotiplerin genom düzeyinde katlanma olmadığ $(2 \mathrm{n}=2 \mathrm{x})$ belirlenmiştir (Şekil 6). FC analizinin, çoğu bitki türünde poliploidi tespiti için kullanılan ve kromozom sayımına göre kolaylık sağlayan etkin bir yöntem olduğu (Prado ve ark., 2010; Xie ve ark., 2015; Sattler ve ark., 2016) bu çalışmayla da doğrulanmıştır.

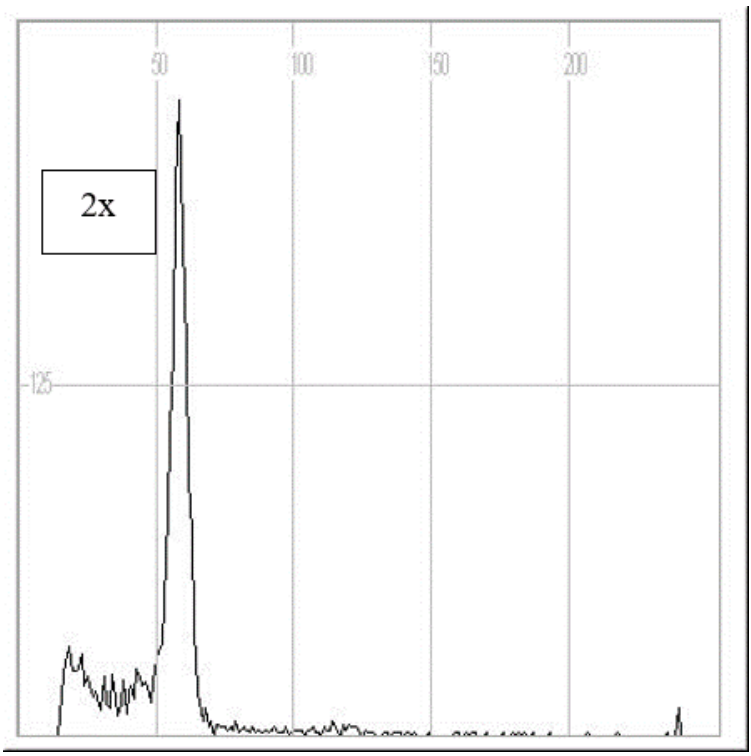

Şekil 6. 'Ekşi Kara' $20 \mathrm{mg} \mathrm{L}^{-1}$, diploid bitkinin $(2 \mathrm{n}=2 \mathrm{x}) \mathrm{FC}$ analiz sonucu

Figure6. 'Ekşi Kara' $20 \mathrm{mg} \mathrm{L}^{-1}$, FC analysis result of diploid plant $(2 n=2 x)$

\section{Sonuç}

Poliploidizasyon, ototetraploid veya allopoliploid genotiplerin elde edilmesini ve çeşitlerin agronomik özelliklerinde iyileştirme yapılmasını kolaylaştıran önemli bir 1slah yöntemidir. In vitro yöntemler, poliploidi gibi sslah çalışmalarında yoğun olarak kullanılmakla birlikte dış koşullara alıştırma aşamasında bitkiciklerin önemli bir kısmının canlılıklarını devam ettiremediği bilinmektedir. Çalışmada, diploid bitkicikler alıştırma sürecini başarıyla geçerken ploidi uyarımının kloroplast sayımlarıyla tespit edildiği 416 bitkiciklerde bu başarıya ulaşılamamıştır. Kolhisin uygulamalarıyla stomal özelliklerin önemli oranda etkilendiği, yerli ve yöresel öneme sahip üzüm çeşitlerinin geliştirilmesinde in vitro yöntemlere başvurulabileceği anlaşılmıştır. Üzerinde çalışılan çeşitler için in vitro boğum kültürü protokolleri oluşturulmuştur. $\mathrm{Bu}$ çalışmadan elde edilen başarılı protokollerin, farklı eksplant tiplerinde, farklı gelişme aşamalarında ve farklı sürelerle uygulanmasıyla asma ıslahında ilerlemeye katk1 sunulabileceği düşünülmektedir. 


\section{Teşekkür}

$\mathrm{Bu}$ çalışma Selçuk Üniversitesi BAP koordinatörlüğü tarafindan 15101013 nolu doktora tez projesi ile desteklenmiştir.

\section{Kaynaklar}

Acanda, Y., Prado, M., González, M., Rey, M., 2013. Somatic embryogenesis from stamen filaments in grapevine (Vitis vinifera L. cv. Mencía): changes in ploidy level and nuclear DNA content. In Vitro Cellular \& Developmental Biology-Plant, $\quad 49 \quad$ (3): $\quad 276-284$. https://doi.org/10.1007/s11627-013-9499-7

Aleza, P., Juárez, J., Ollitrault, P., Navarro, L., 2009. Production of tetraploid plants of non apomictic citrus genotypes. Plant cell reports, 28 (12): 1837-1846. https://doi.org/10.1007/s00299-009-0783-2

Chen, L., Gao, S., 2007, In vitro tetraploid induction and generation of tetraploids from mixoploids in Astragalus membranaceus. Scientia horticulturae, 112 (3): 339-344. https://doi.org/10.1016/j.scienta.2006.12.045

Cohen, H., Fait, A., Tel-Zur, N., 2013. Morphological, cytological and metabolic consequences of autopolyploidization in Hylocereus (Cactaceae) species. BMC plant biology, $13 \quad$ (1): 173. https://doi.org/10.1186/1471-2229-13-173

Dami, I., Hughes, H., 1995. Leaf anatomy and water loss of in vitro PEG-treated 'Valiant'grape. Plant cell, tissue and \begin{tabular}{llll} 
organ & culture, & 42 & (2): \\
\hline
\end{tabular} https://doi.org/10.1007/BF00034236

Di Genova, A., Almeida, A., Muñoz-Espinoza, C., Vizoso, P., Travisany, D., Moraga, C., Pinto, M., Hinrichsen, P., Orellana, A., Maass, A., 2014. Whole genome comparison between table and wine grapes reveals a comprehensive catalog of structural variants. BMC plant biology, 14 (1): 7. https://doi.org/10.1186/1471-2229-14-7

Ekbiç, H., Tangolar, S., 2016. Trakya İlkeren ve Flame Seedless üzüm çeşitlerinde farklı kolhisin dozları kullanılarak poliploidi oluşturma olanakları. Akademik Ziraat Dergisi, 5 (2): 69-76.

Gray, D., Benton, C., 1991. In vitro micropropagation and plant establishment of muscadine grape cultivars (Vitis rotundifolia). Plant cell, tissue and organ culture, 27 (1): 7-14. https://doi.org/10.1007/BF00048199

Huy, N., Luan, V., Tung, H., Hien, V., Ngan, H., Duy, P., Nhut, D., 2019. In vitro polyploid induction of Paphiopedilum villosum using colchicine. Scientia horticulturae, 252: 283-290. https://doi.org/10.1016/j.scienta.2019.03.063

Kara, Z., Demirhan, Y., 2005. Bazı sofralık ve şaraplık üzüm çeşitlerinin Konya yöresindeki vegetatif gelişme ve verim değerleri. Tekirdağ Bağcılık Araştırma Enstitüsü. Türkiye, 6: 375-382.

Kara, Z., Sabır, A., Yazar, K., Doğan, O., Omar, A., 2017. Fruitfulness of Ancient Grapevine Variety 'Ekşi Kara' (Vitis vinifera L.). Selçuk Tarım ve Gıda Bilimleri Dergisi. 31 (3): 62-68. http://dx.doi.org/10.15316/SJAFS.2017.36
Kumar, K., Rao, I., 2012. Morphophysiologicals problems in acclimatization of micropropagated plants in-ex vitro conditions. A Reviews, 271-283.

Kunter, B., Karataş, D., 2011. Asmalarda Mutasyonlar ve Mutant Vitis vinifera L. Çeşitleri. Yüzüncü Y1l Üniversitesi Tarım Bilimleri Dergisi, 21 (2): 146-151.

Mbah, E., Wakil, S., 2012. Elimination of bacteria from in vitro yam tissue cultures using antibiotics. Journal of Plant Pathology, 94 (1): 53-58.

Moghbel, N., Borujeni, M., Bernard, F., 2015. Colchicine effect on the DNA content and stomata size of Glycyrrhiza glabra var. glandulifera and Carthamus tinctorius L. cultured in vitro. Journal of Genetic Engineering and Biotechnology, $13 \quad$ (1): $1-6$. https://doi.org/10.1016/j.jgeb.2015.02.002

Murashige, T., Skoog, F., 1962. A revised medium for rapid growth and bio assays with tobacco tissue cultures. Physiologia plantarum, 15 (3): 473-497.

Notsuka, K., Tsuru, T., Shiraishi, M., 2000. Induced polyploid grapes via in vitro chromosome doubling. Journal of the Japanese Society for Horticultural Science, 69 (5): 543551. https://doi.org/10.2503/jjshs.69.543

OIV, 2017a. Distribution of the world's grapevine varieties. http://www.oiv.int/public/medias/5888/en-distribution-ofthe-worlds-grapevine-varieties.pdf (Erişim Tarihi: 8.9.2018).

OIV, 2017b. 2017 World Vitiviniculture Situation. http://www.oiv.int/public/medias/5479/oiv-en-bilan2017.pdf. (Erişim Tarihi: 08.09.2018).

Olmo, H., 1937. Chromosome numbers in the european grape (Vitis vinifera). Cytologia (1): 606-613. https://doi.org/10.1508/cytologia.FujiiJubilaei.606

Planchais, S., Glab, N., Inzé, D., Bergounioux, C., 2000. Chemical inhibitors: a tool for plant cell cycle studies. Febs $\quad$ Letters, $476 \quad$ (1-2): 78-83. https://doi.org/10.1016/S0014-5793(00)01675-6

Prado, M., Rodriguez, E., Rey, L., González, M., Santos, C., Rey, M., 2010. Detection of somaclonal variants in somatic embryogenesis-regenerated plants of Vitis vinifera by flow cytometry and microsatellite markers. Plant Cell, Tissue and Organ Culture (PCTOC), 103 (1): 49-59. https://doi.org/10.1007/s11240-010-9753-1

Ramsey, J., Schemske, D., 1998, Pathways, mechanisms, and rates of polyploid formation in flowering plants, Annual Review of Ecology and Systematics, 29 (1), 467-501.

Sattler, M., Carvalho, C., Clarindo, W., 2016. The polyploidy and its key role in plant breeding. Planta, 243 (2): 281296. https://doi.org/10.1007/s00425-015-2450-X

Sinski, I., Dal Bosco, D., Pierozzi, N., Maia, J., Ritschel, P., Quecini, V., 2014. Improving in vitro induction of autopolyploidy in grapevine seedless cultivars. Euphytica, 196 (2), 299-311. https://doi.org/10.1007/s10681-0131034-8

Tepe, Ş., Ellialtıoglu, Ş., Yenice, N., Tipirdamaz, R., 2002. In vitro kolhisin uygulaması ile poliploid nane (Mentha 
longifolia L.) bitkilerinin elde edilmesi. Mediterranean agricultural sciences, 15 (2): 63-69.

Torregrosa, L., Bouquet, A., Goussard, P., 2001. In vitro culture and propagation of grapevine, In: Molecular Biology \& Biotechnology of the Grapevine. Eds: Springer, 281-326. https://doi.org/10.1007/978-94-017-2308-4 12

TÜİK, 2018. http://www.tuik.gov.tr/Start.do. (Erişim Tarihi:08.09.2018).

Väinölä, A., 2000. Polyploidization and early screening of Rhododendron hybrids, Euphytica, 112 (3), 239-244. https://doi.org/10.1023/A:1003994800440

Xie, X., Agüero, C., Wang, Y., Walker, M., 2015. In vitro induction of tetraploids in Vitis $\mathrm{x}$ Muscadinia hybrids. Plant cell, tissue and organ culture, 122 (3): 675-683. https://doi.org/10.1007/s11240-015-0801-8

Yamada, M., Sato, A., 2016. Advances in table grape breeding in Japan. Breeding science, 66 (1): 34-45. https://doi.org/10.1270/jsbbs.66.34

Yang, X., Cao, Z., An, L., Wang, Y., Fang, X., 2006. In vitro tetraploid induction via colchicine treatment from diploid somatic embryos in grapevine (Vitis vinifera L.). Euphytica, $\quad 152 \quad$ (2): $217-224$. https://doi.org/10.1007/s10681-006-9203-7

Yuan, S., Liu, Y.M., Fang, Z.Y., Yang, L.M., Zhuang, M., Zhang, Y.Y., Sun, P.T., 2009. Study on the relationship between the ploidy level of microspore-derived plants and the number of chloroplast in stomatal guard cells in Brassica oleracea. Agricultural Sciences in China, 8 (8): 939-946. https://doi.org/10.1016/S1671-2927(08)60298-9

Yue, Y., Zhu, Y., Fan, X., Hou, X., Zhao, C., Zhang, S., Wu, J., 2017. Generation of octoploid switchgrass in three cultivars by colchicine treatment. Industrial Crops and Products, 107 ,

20-21. https://doi.org/10.1016/j.indcrop.2017.05.021

Zhou, J., Guo, F., Fu, J., Xiao, Y., Wu, J., 2020. In vitro polyploid induction using colchicine for Zingiber officinale roscoe cv.'Fengtou'ginger. Plant Cell, Tissue and Organ Culture (PCTOC), 1-8. https://doi.org/10.1007/s11240-020-01842-1

Ziv, M., 1995. In vitro acclimatization, In: Automation and environmental control in plant tissue culture. Eds: Springer, 493-516. https://doi.org/10.1007/978-94-0158461-6_20 